\title{
ECONOMIC PRINCIPLES OF TAXATION: PROBLEMS OF DEFINITION AND EMBODIMENT IN THE TAX LEGISLATION OF UKRAINE AND THE EUROPEAN STATES
}

\author{
Olha Dmytryk', Oksana Makukh²
}

\begin{abstract}
Today, almost every state feels the impact of the financial crisis and is looking for ways to overcome it. It is obvious that the development of economic relations of any state is influenced by taxation, and through taxes, the state has an impact on the property of individuals and legal entities. At the same time, establishing the optimum level of taxation for both taxpayers and the state is an important factor for economic uplift, ensuring the balance of public and private interests in tax and legal regulation, under which there is a proper financial support for the performance of the tasks and functions by the public authorities with reasonable and justified interference of the state in the right of private ownership of persons by means of the taxes. The construction of the tax system, the amount of taxes and their rates should not depend solely on the funds necessary for the state. This process is also influenced by other factors that find their objectification in the relevant principles, because taxation should be reasonable. The purpose of the article is to characterize certain economic principles, which should be the basis of taxation and which should be defined in tax legislation. This will be performed with the dogmatic method, the methods of analysis and synthesis, the systemic method and the case study method. The basis for building the tax system, determining the amount of taxes, the size of their rates, is in the economic factors, which should be taken into account to ensure the effectiveness of taxation and tax regulation as a whole. They have their reflection in the relevant principles as the initial provisions of taxation, acting as fundamental in regulating tax relations. The range of economic principles, which taxation is based on, and the content of which is currently debated in scientific circles, is as follows: proportionality (taxability), cost-effectiveness of taxation, fiscal sufficiency, economic basis of tax, economic justification for tax. They do not exist in isolation from each other, but constitute a clear system, in which their logical connection and influences are traced. Results. Proportionality as a principle of taxation is determined by analyzing the payer's financial position, the actual ability to pay taxes, and the economic benefit he/she receives in the course of paying taxes and fees (the economic result of the payer). The principle of cost-effectiveness of taxation means that the establishment of taxes and fees should be such that the amount of revenues from their payment to the budget exceeds public expenditure and leads to effective taxation (the economic result of the state). The principle of tax sufficiency provides a reasonable restriction on those public needs that need to be met through taxpaying, since these needs cannot be absolute. The principle of the economic basis of the tax indicates source for its payment, which is formed by the corresponding taxation of transactions or other taxable objects. The principle of economic justification for the tax determines the set of relevant factors that allow to approach the characteristics of taxation in different ways, taking into account certain economic indicators, by ensuring that the balance of private and public interests in tax and legal regulation is achieved. In fact, it combines an assessment of compliance with the principles of proportionality (taxability), costeffectiveness of taxation, tax sufficiency, and the economic basis of tax. The results obtained are original, they will allow to improve the normative provisions before consolidating the principles of taxation in tax legislation.
\end{abstract}

Key words: tax, taxation, principles of taxation, cost-effectiveness of taxation, economic basis of tax, economic justification for tax.

JEL Classification: K34, H2O, H30

Corresponding author:

${ }^{1}$ Yaroslav Mudryi National Law University, Ukraine;

Scientific and Research Institute of Providing Legal Framework

for the Innovative Development of the National Academy of Legal Sciences of Ukraine, Ukraine.

E-mail: omzdch@gmail.com

ORCID: https://orcid.org/0000-0001-5469-3867

${ }^{2}$ Institute of Law named after Volodymyr Stashys of the Classic Private University, Ukraine.

E-mail: omakukh@gmail.com

ORCID: https://orcid.org/0000-0001-7410-5081 


\section{Introduction}

Today, almost every state feels the impact of the financial crisis and is looking for ways to overcome it. It is obvious that the development of economic relations of any state is affected by taxation (Macek, 2015; William G. Gale, 2014). As stated in Art. 11 of the First Protocol to the Convention for the Protection of Human Rights and Fundamental Freedoms, every individual or legal entity is entitled to the peaceful enjoyment of his/her property. No one shall be deprived of his/her property except in the public interest and subject to the conditions provided for by law and by the general principles of international law. The preceding provisions shall not, however, in any way impair the right of a state to enforce such laws as it deems necessary to control the use of property in accordance with the general interest or to secure the payment of taxes or other contributions or penalties (Protocol of the Convention for the Protection of Human Rights and Fundamental Freedoms, 1997). In fact, through taxes, the state has an impact on the property of individuals and legal entities. Thus, taxes are now an attribute of any state, because of their force on the economic activities of the entities, they play a significant role in the economic development of the state. At the same time, establishing the optimum level of taxation for both taxpayers and the state is an important factor for economic uplift, ensuring the balance of public and private interests in tax and legal regulation, under which there is a proper financial support for the performance of the tasks and functions by the public authorities with reasonable and justified interference of the state in the right of private ownership of persons by means of the taxes.

The structure of the tax system, the amount of taxes and their rates should not depend solely on the revenue required by the state and territorial communities. Obviously, this process is influenced by other factors because taxation should be reasonable. It is a very important and not easy task to mark them. The fact is that the tax is both a legal and economic category. This means that the establishment of taxes must take place on an economic basis, that is, in view of those economic laws in force in society. And here a rather difficult question arises: how and on what economic grounds taxation should be based, and whether such principles can and should be enshrined in tax and legal rules. Typically, this is resolved by enshrining in tax law the principles on which taxation should be based. For example, in the Tax Code of Ukraine it is Art. 4, entitled "Basic Principles of Tax Law" (The Tax Code of Ukraine, 2010). Thus, the purpose of the article is the designation and characterization of certain economic principles, which taxation should be based on and which should be defined in tax legislation. This will be done with the dogmatic method, the methods of analysis and synthesis, the systemic method and the case study method.

\section{Principles applicable in tax and legal regulation}

The tasks to establish optimum taxation, to mark all the necessary aspects in the tax and legal rules clearly are not easy. It is not by chance that scientists emphasize the complexity of tax law, noting that, like the complexity of the relationship of commerce to which it applies, it is often seen as increasing exponentially, with boosting pressure on taxpayers, tax advisors, and tax administrations (Evans, Freedman, Krever, 2011). In such circumstances, the use of principles constituting ideas, requirements and underlying, basic, and fundamental provisions in regulating relevant relationships, is well justified (Pohrebniak, 2008). Principles of tax and legal regulation are objectively determined by the economic, social and political structure of the state, the basic principles of the construction and functioning of society, etc. Their value is also seen in the fact that they are designed to provide organic communication, unity and systematicity of tax law rules (Shaptala, 2012).

Today, in Art. 4 of the Tax Code of Ukraine, the following principles are enshrined, such as: universality of taxation, equality of all taxpayers, prevention of any manifestation of discrimination, inevitability of statutory liability occurrence in case of violation of tax legislation, presumption of lawfulness of decisions of the taxpayer, tax sufficiency, social justice, stability, uniformity and convenience, the only approach to setting taxes and fees (The Tax Code of Ukraine, 2010). The analysis of the stated norm allows to take note that the legislator does not consider it appropriate to group such principles to some extent. At the same time, it is obvious that some of the principles are based on laws that have the logic of the functioning of economic phenomena as their source, that is, they are economic (they are called classic by the academic economists). The other principles are legal (neoclassic). The fact that in the vast majority of taxation principles that determine the ordering of the taxation system, the laws of economic theory are fundamental factors, is unconditional (Braslavskyi, 2019). Here we give the words of I.I. Kucherov, who noted that it is the economic principles of taxation that outline the basic requirements, with which taxes must conform from the point of the economic theory. For example, he cites the principles of economic justification for taxation and proportionality, which make it possible to define approaches to the implementation of mandatory tax payments as a component of the economic system (Kucherov, 2009).

Significantly, it is often stated in the legal and economic literature that the principles of taxation of his time were outlined by A. Smith, who referred to them: proportionality is when taxpayers are required to participate in taxation in accordance with their taxability, in proportion to the income received under 
the protection of the state; certainty means that the tax must be clearly established and reasoned, and the payment term, method and amount of payment must be accurately pre-determined, justified and known to payers and other taxpayers; convenience is that the time and method of paying taxes should be as convenient as possible for the payer; cost-effectiveness of taxation is understood as the tax must be constructed so that it takes as little as possible out of the payer's pocket what he/she brings to the treasury (Smith, 1962). Paying great tribute to the scientist, let us point out that the above principles are to some extent the basis of the tax system of many modern states. However, over time, the content of some of them has changed, has taken on a new meaning, and some of the above, on the contrary, have been fixed in essence, while their name has been changed. In addition, such principles as the principle of certainty, convenience only with a certain reservation can be attributed to economic principles.

The European Court of Human Rights frequently refers to this principle. For example, in the decision in the case of "N.K.M. v. Hungary" dated May 14, 2013, the court notes that the state's interference with the property rights of persons should take into account the "just balance" between the needs of the general interest of society and the requirements of protection of fundamental human rights, which must be justified by the proportionality between the means used and the purpose established (Decision of the European Court of Human Rights, 2013). Unfortunately, there is no direct embodiment of this basis in the current Ukrainian tax legislation. This was done through the construction of the principle of justice of taxation, since in the decision dated March 24, 2005, the Constitutional Court of Ukraine stated that proportionality was an element of the principle of justice (Decision of the Constitutional Court of Ukraine, 2005). Justice was recognized by the Constitutional Court of Ukraine in its Decision dated November 2, 2004 as a fundamental principle for the rule of law, a decisive regulator of social relations, and one of the universal dimensions of law (Decision of the Constitutional Court of Ukraine, 2004). As for taxation, it is enshrined in the Tax Code of Ukraine as "social justice".

In our view, justice is a very capacious concept, so defining its content depends on numerous factors of social development. It is logical that the breadth of its content leads to the existence of an approach in which social justice cannot be a simple reconciliation of the size of the tax payment with the solvency of the obliged person. N.K. Shaptala rightly notes that the principle of social justice is much broader than the literal connection between the ability to pay taxes and fixing their amounts, because it serves as a systemically important factor, according to the content of which regulation of the law of tax relations, the formation of the entire system of principles of tax law, as well as the process of the enforcement of right should be performed. The content of the principle under consideration in its tax and legal regulation is not only to properly establish the legal status of the taxpayer. Justice must ensure the effectiveness of legal remedies for the protection of the rights and interests of taxpayers, as well as the application of proportionate punishment for violations of tax legislation (Shaptala, 2012). Such an opinion does not raise objections. Therefore, the above points to a distinction between the principles of justice and the principle of proportionality related to taxability.

At the same time, another problem arises: how exactly should proportionality be assessed; which basis should be for observing this principle. Here we give the opinion of S.Ye. Fedorov, who proposes approaches to assessing the solvency of the payer to form on the basis of economic science, since when determining the solvency of certain groups of population or individuals must take into account the economic indicators. To this end, the scientist points to the need to involve in the development of legal acts in the field of taxation of experts in the economy, who would make calculations based on economic indicators of solvency of taxpayers (Fedorov, 2017). The experience of Germany, described by Sh. Rekcigel, can be acceptable here. The scientist writes about the actual ability of the payer to pay the tax, considering it in the context of the analysis of the principle of equality under the law. Thus, Sh. Rekcigel argues that the same or similar factual circumstances should have the same (similar) consequences, which indicates that taxpayers are equally burdened. With regard to taxpayers' taxability, it is specified by the principle of "net income", because taxability arises only when the recipient of income creates for him/herself the conditions of earning and provides the necessary financial guarantees of its existence, while the legislator is not obliged to allow deductions of actually effected expenditures, but may determine their types (incomerelated expenditures are implied) (Rekcigel, 2010). Such opinions are worthy of support and require that they be to some extent labeled and enshrined in law. Therefore, the proportionality is determined by analyzing the payer's property status, the actual ability to pay taxes, and the economic benefits that he/she has in the course of paying taxes and fees must be determined. In other words, we are talking about the economic result that the payer receives and remains with him/her after paying taxes and fees (the economic result of the payer).

\section{Principles of cost-effectiveness, economic justification for the tax, the economic basis of the tax and tax sufficiency: approaches to differentiation}

As it seems, in this case it is appropriate to mention the principle of economic justification for the tax, which is also not currently embodied in the Tax Code of Ukraine. 
In this case, quite often, this principle is identified with the principles of cost-effectiveness, economic basis of tax, tax sufficiency. Let us consider them.

Thus, the cost-effectiveness of taxation in p. 4.1.7 Clause 4.1 Art. 4 of the Tax Code of Ukraine is associated with the fact that the imposition of taxes and fees should be such that the amount of revenues from their payment to the budget significantly exceeds the cost of their administration (The Tax Code of Ukraine, 2010). However, as K.O. Hetman writes, taxes and fees should be aimed not only at exceeding the costs of administering them, but also at setting up an appropriate fund, at the expense of which numerous needs, financially satisfying the performance of functions of the state or territorial community, must be met (Hetman, 2015). Indeed, given the content of this principle, it can be argued that it causes the formation at taxation of certain grounds to characterize its effectiveness. The latter will be zero if all funds received from tax revenue are used to administer these payments. Therefore, it is important not just the minimal excess of tax revenue (the amount of which must be higher) over the cost of administering it, but a significant difference between them (Shaptala, 2012). Significantly, in Germany, where there is a complex and extensive tax system, one of the principles of its construction is the principle, according to which the value of taxes should correspond to the size of public services, including protection of the citizen and all that the citizen can get from the state (Larionova, 2015). We agree with these positions, because taxes, through the exercise of their fiscal function, should ensure the realization of a wide range of public needs, one of which is certainly the administration of taxes. That is why the principle of cost-effectiveness of taxation should be considered as one that determines when taxing the flow of funds to ensure public expenditure and ultimately determines the most effective taxation (the economic result of the state).

Obviously, following the broad approach to the content of the principle of economical taxation we have proposed, it is necessary to address the question of a reasonable restriction on those public needs that must be met at the expense of tax payments, since these needs cannot be absolute, limitless. In this context, it is necessary to mention the principle of tax sufficiency, which according to Clause 4.1.5. Art. 4 of the Tax Code of Ukraine means the establishment of taxes and fees, taking into account the need to achieve a balance of budget expenditures with its revenues (The Tax Code of Ukraine, 2010). This principle seems to be interpreted in Italy as well, since it means that the level of taxation of the entire enterprise must generally be limited by the sufficiency of the budget's revenue base, which is determined in accordance with the state's fiscal policy (Gandullia, 2012). The analysis of the mentioned provisions shows that taxation is not an end in itself, because it is not just for the formation of revenue parts of the budget, but for ensuring the fulfillment of all tasks and functions of the state and territorial communities. In addition, this principle also provides for some restriction on the arbitrariness of the legislator in setting taxes and fees, since the size and types of the latter may not be infinite, they should only provide the necessary budgetary contributions to different levels. In view of the above, it is possible to note the close relationship between the principles of economy and tax sufficiency.

With regard to the principle of economic justification, scientists consider its content in different ways. For example, Ye.V. Timofieiev argues that this principle means that the tax should be consistent with the task that was originally laid down for it. For example, he cites the following example: if income is taxed within income tax, it means that taxation is income that is determined by the rules of tax legislation. However, in the case where certain costs are not deductible, according to his approach, the principle of economic justification is violated (Zubareva, 2009). This approach is unlikely to be constructive for such reasons. Firstly, traditionally, the characteristics of taxes are determined not by their tasks but by their functions. The latter reflect their dynamic content, emphasize the focus of tax and legal regulation (Kucheryavenko, 2005). These include fiscal, regulatory, controlling, distributive, incentive, cumulative. At present, fiscal function has ceased to be unique, since the development of the state necessitates the use of tax as an effective instrument of redistributive processes, which has an impact on reproduction, stimulating or holding back its pace, enhancing or weakening capital accumulation. As a rule, when paying the tax, the implementation of all these functions is performed, but some function will be leading (for example, fiscal), others (for example, incentive is by providing benefits to a certain category of economic entities) will be additional. Thus, the economic justification cannot be based solely on the correspondence to the task, which has been initially included in the tax, its meaning is much wider. Secondly, a specialist is likely to mix the economic basis of the tax with its economic justification. In our view, the economic basis of the tax is source for its payment, which is formed by the taxable transactions or other taxable objects. In other words, we should talk about the proper definition of the object of taxation. At the same time, this process should also be found on the economic basis. This means that in the process of selecting and fixing the taxable object, the legislator must proceed from the potential of one or another object to use or generate income in the economic (business) activity of the taxpayer, and to eliminate the unjustified financial burden for that taxpayer (Polishchuk, 2018).

When considering the economic basis of the tax, one should mark another position that is significantly different from the above. Thus, H.B. Sereda builds on the characterization of such a framework based on the following considerations: (a) the basis is a necessary, 
determining condition for the existence of any phenomenon, which is also its explanation; (b) for this reason, the condition is linked to the imposition of tax and the obligation to pay it; (c) the basis can be considered broadly (as the needs of the state or the benefits of the society) or narrow (the taxpayer's ability to pay, the circumstances and facts that prove the benefits, etc.); (d) there are two groups of foundations: from the standpoint of public interest they serve the public needs, because of the existence and necessity of implementation the use of taxes is explained; from the point of view of the interests of the payer, participation of the state in public life, conditioned by the need of any business entity in obtaining their income. As a result, H.B. Sereda states that the general basis of the tax is the economic and legal factors that explain the need to meet state and economic needs in accordance with the requirements of the economy and law (Sereda, 2013). In our opinion, the mentioned approach has the right to exist, because all the principles we have talked about are closely related to each other, and the content of a particular principle is determined taking into account the content of another. This suggests that such principles do not exist in isolation from each other, but constitute a clear system in which their logical connection and influences are traced. At the same time, there is a disagreement with the author's position that the reason for the occurrence of a tax liability is not only the existence of the object of taxation, but in general the need of the state in cash. Adhering to this approach will make it very difficult to determine the moment when the taxpayer's tax liability arises, which provokes numerous tax disputes. Therefore, it is more appropriate to talk about the economic basis of the tax in the context of the availability of those objects that are determined as the taxable.

The position of A. Blankenagel is quite balanced on that the taxes are economically justified. Thus, he differentiates the following criteria for evaluation: (1) taking into account the ability of the payer to pay taxes due to the different levels of income of individuals; (2) the existence of a tax ban on the part of the payer's income that is necessary for him/her to maintain his/her existence; (3) taxation of the taxpayer's net income only (net principle); (4) the existence of a double taxation ban; (5) the ability to achieve the desired goal for the state; (5) reasonable restriction on government spending, promoting economic development (Blankenagel, 2010). As we can see, the scientist focuses on a set of characteristics that allow us to talk about the economic justification. There are the similar thoughts of the others when they argue that the economic justification for the tax should include: 1) justification of the concept of a specific tax in relation to the object of taxation, taxpayers and tax carriers; 2) goal setting and development of tax concepts (models); 3) comparative analysis of compliance of the mechanism of tax conception (models); 4) assessment of compliance of tax models with the basic principles of taxation; 5) assessing the compliance of tax models with tax policy objectives (Kuzmenko, Beskorovaynaya, Bagdasaryan, 2013). The view of Ya.V. Polishchuk, who, given the semantic interpretation of the term "justification" (according to which it is treated as the totality of the facts, the arguments for believing anything, in the presentation of evidence to support any convincing evidence, facts, etc.), connects the economic justification with defining facts, which will be forcible arguments to convince of expedience of the taxation. At the same time, she suggests the following facts: the effectiveness of taxes, their collection and regulatory impact (Polishchuk, 2018).

The following points of view attest to the fact that the economic justification of the tax is a set of relevant factors that allow, taking into account certain economic indicators, to approach the characteristics of taxation differently by ensuring a balance of private and public interests in tax and legal regulation. This is due to the fact that for the payer, first of all, it will be possible to take into account his/her ability to pay taxes, the presence of the object of taxation and the source of tax. The state, through economic justification, indicates the needs that are necessary to be met at the expense of tax payments, and restricts the right to set taxes, specifies the limit, to which the corresponding public needs are, and the purpose of establishing taxes.

\section{Conclusions}

The basis for building the tax system, determining the amount of taxes, the size of their rates, is in the economic factors, which should be taken into account to ensure the effectiveness of taxation and tax regulation as a whole. They have their reflection in the relevant principles as the initial provisions of taxation, acting as fundamental in regulating tax relations. The range of economic principles, on which taxation is based, and the content of which is currently debated in scientific circles, is as follows: proportionality (taxability), costeffectiveness of taxation, tax sufficiency, economic basis of tax, economic justification for tax. They are closely related to each other, and the determination of the content of a particular principle is based on taking into account the meaning of another. This suggests that such principles do not exist in isolation from each other, but constitute a clear system, in which their logical connection and influences are traced.

Proportionality as a principle of taxation is determined by analyzing the payer's financial position, the actual ability to pay taxes, and the economic benefit he/she receives in the course of paying taxes and fees (the economic result of the payer). The principle of costeffectiveness of taxation means that the establishment of taxes and fees should be such that the amount of revenues from their payment to the budget exceeds 
public expenditure and leads to effective taxation (the economic result of the state). The principle of tax sufficiency provides a reasonable restriction on those public needs that must be met at the expense of taxation, since these needs cannot be absolute; taxes are not an end in themselves, they are paid not only for the formation of revenue parts of the budgets, but for the purpose of ensuring the fulfillment of the tasks and functions of the state and territorial communities. The principle of the economic basis of the tax indicates source for its payment, which is formed by the corresponding taxation of transactions or other taxable objects. When marking the object of taxation, the legislator should be guided by the existence of the potential possibility of one or another object to use in the economic (business) activity of the taxpayer or to bring him/her income, and to eliminate the unjustified financial burden for that payer.
The principle of economic justification for the tax determines the set of relevant factors that allow to approach the characteristics of taxation in different ways, taking into account certain economic indicators, by ensuring that the balance of private and public interests in tax and legal regulation is achieved. In fact, it combines an assessment of compliance with the principles of proportionality (taxability), costeffectiveness of taxation, tax sufficiency, and the economic basis of tax. Through economic justification, the state indicates the needs that are necessary to be met at the expense of tax payments, and restricts the right to set taxes, specifies the limit, to which the corresponding public needs are, and the purpose of establishing taxes.

The results obtained will allow to improve the legislative approaches to consolidate the principles of taxation in tax legislation.

\section{References:}

Blankenagel, A. (2010). Konstitutsionnoye ponimaniye i funktsii ekonomicheski obosnovannykh nalogov $s$ tochki zreniya spetsialista iz Germanii [Constitutional understanding and functions of economically sound taxes - from the point of view of a specialist from Germany]. Proceedings of the Nalogovoye pravo $v$ resheniyakh Konstitutsionnogo Suda Rossiyskoy Federatsii 2008 goda: VI mezhdunar. nauch.-prakt. konf. (Russia, Moskow, April 17-18, 2009). Moskva: Statut, pp. 53-65.

Braslavskkyi, R. H. (2019). Pryntsypy podatkovoho prava Ukrainy [Principles of tax law of Ukraine]. Zaporizhzhia. Evans, C., Freedman, J., \& Krever, R. (2011). Preface. The Delicate Balance: Tax, Discretion and the Rule of Law. Amsterdam: IBFD. P. V.

Fedorov, S. Ye. (2017). Pryntsyp sotsialnoi spravedlyvosti podatkovoi systemy Ukrainy yak otsinne poniattia [The principle of social justice of the tax system of Ukraine as an evaluation concept]. Pidpryiemnytstvo, hospodarstvo, parvo - Entrepreneurship, economy, law, no. 10, pp. 160-165.

Gandullia, L. (2012). The role of direct taxes in fiscal decentralization. Available at: ftp://ftp.repec.org/opt/ ReDIF/RePEc/gea/wpaper/dwpo-6-sep2012.pdf (accessed March 23, 2020).

Hetman, K. O. (2015). Pravova pryroda fiskalnoi funktsii podatkiv [Legal nature of fiscal function of taxes]. (PhD Thesis), Kharkiv.

Kucherov, I. I. (2009). Teoriya nalogov i sborov (pravovyye aspekty) [Theory of taxes and fees (legal aspects)]. Moskva: ZAO «YurInfoR».

Kucheryavenko, N. P. (2005). Kurs nalogovogo prava (Vols. 1-6); Vol. III: Ucheniye o naloge [The course of tax law. Doctrine of tax]. Kharkov: Legas; Pravo.

Kuzmenko, V. V., Beskorovaynaya, N. S., \& Bagdasaryan, L. Yu. (2013) Ekonomicheskoye obosnovaniye izmeneniy $v$ nalogovom zakonodateltsve. Available at: http://naukarus.com/ekonomicheskoe-obosnovanie-izmeneniy-vnalogovom-zakonodatelstve (accessed March 24, 2020).

Larionova, A. A. (2015). Sravnitelnyy analyz nalogovykh sistem Rossii i Germanii. Available at: https://cyberleninka.ru/ article/n/sravnitelnyy-analiz-nalogovyh-sistem-rossii-i-germanii.pdf (accessed March 25, 2020).

Macek, R. (2015). The Impact of Taxation on Economic Growth: Case Study of OECD Countries. Available at: https://www.researchgate.net/publication/276088447_The_Impact_of_Taxation_on_Economic_Growth_ Case_Study_of_OECD_Countries (accessed March 29, 2020).

Podatkovyi kodeks Ukrainy (2010) vid 2 hrudnia 2010 r. № 2755-VI. Available at: https://zakon.rada.gov.ua/ laws/show/2755-17 (accessed March 27, 2020).

Pohrebniak, S. P. (2008). Osnovopolozhni pryntsypy prava (zmistovna kharakterystyka) [Fundamental principles of law (meaningful characteristic)]. Kharkiv: Pravo. (in Ukrainian)

Polishchuk, Ya. V. (2018). Stavka podatkiv ta zboriv: pravova pryroda i klasyfikatsiia [Tax rates: legal nature and classification] (PhD Thesis), Irpin.

Protokol Konventsii pro zakhyst prav liudyny i osnovopolozhnykh svobod (1997). Available at: https://zakon.rada.gov.ua/laws/show/994_535 (accessed March 27, 2020).

Rektsigel, Sh. (2010). Primeneniye Konstitutsionnym Sudom FRG printsipov nalogooblozheniya [The application of the principles of taxation by the Constitutional Court of Germany]. Proceedings of the Nalogovoye pravo $v$ resheniyakh Konstitutsionnogo Suda Rossiyskoy Federatsii 2008 goda: VI mezhdunar. nauch.-prakt. konf. (Russia, Moskow, April 17-18, 2009). Moskva: Statut, pp. 219-223. 
Rishennia Konstytutsiinoho Sudu Ukrainy (2005) vid 24 bereznia 2005 r., № 2-rp/2005 u spravi po konstytutsiinomu zvernenniu 48 narodnykh deputativ Ukrainy pro vidpovidnist Konstytutsii Ukrainy (konstytutsiinosti) polozhen punktu 1.17 statti 1, statti 8 Zakonu Ukrainy «Pro poriadok pohashennia zoboviazan platnykiv podatkiv pered biudzhetamy ta derzhavnymy tsilovymy fondamy». Available at: http://zakon3.rada.gov.ua (accessed March 25, 2020).

Rishennia Konstytutsiinoho Sudu Ukrainy (2004) vid 2 lystopada 2004 r., № 15-rp/2004 u spravi za konstytutsiinym podanniam Verkhovnoho Sudu Ukrainy shchodo vidpovidnosti Konstytutsii Ukrainy (konstytutsiinosti) polozhen statti 69 Kryminalnoho kodeksu Ukrainy (sprava pro pryznachennia sudom bilsh miakoho pokarannia). Ofitsijnyj visnyk Ukrainy - Official Gazette of Ukraine. 2014. № 45. Art. 2975.

Rishennia Yevropeiskoho sudu z prav liudyny (2013) u spravi «N.K.M. proty Uhorshchyny» vid 14 travnia 2013 r. Available at: https://www.echr.coe.int (accessed March 25, 2020).

Sereda, S. G. (2013). Printsip ekonomycheskoy obosnovannosti naloga [The principle of economic feasibility of tax]. Nalogi i nalogooblozheniye - Taxes and taxation, no. 7(109), pp. 483-490.

Shaptala, N. K. (2012). Spivvidnoshennia pryntsypiv rivnosti $i$ sotsialnoi spravedlyvosti $v$ podatkovo-pravovomu rehuliuvanni [Correlation between the principles of equality and social justice in tax regulation] (PhD Thesis), Irpin. Smit, A. (1962). Issledovaniye o prirode i prichinakh bogatstva narodov [Research on the nature and causes of the wealth of peoples]. Moskva: Sotsekgiz.

William, G. Gale (2014). Effects of Income Tax Changes on Economic Growth. Available at: https://www.brookings.edu/wp-content/uploads/2016/06/09_effects_income_tax_changes_economic growth_gale_samwick.pdf (accessed March 28, 2020).

Zubareva, I. E. (2009). Printsip ekonomicheskogo osnovaniya nalogov - eto skrytoye oruzhiye nalogoplatelshchika ili deklarativnaya norma [The principle of the economic basis of taxes is a taxpayer's hidden weapon or declarative norm]. Vash nalogovyy advokat - Your tax attorney, no. 5. 